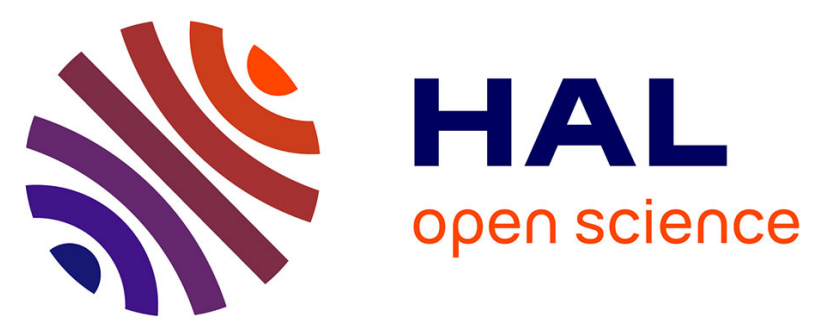

\title{
Modulation of HLA-G and HLA-E expression in human neuronal cells after rabies virus or herpes virus simplex type 1 infections.
}

Françoise Mégret, Christophe Prehaud, Mireille Lafage, Philippe Moreau, Nathalie Rouas-Freiss, Edgardo D Carosella, Monique Lafon

\section{To cite this version:}

Françoise Mégret, Christophe Prehaud, Mireille Lafage, Philippe Moreau, Nathalie Rouas-Freiss, et al.. Modulation of HLA-G and HLA-E expression in human neuronal cells after rabies virus or herpes virus simplex type 1 infections.. Human Immunology, 2007, 68 (4), pp.294-302. 10.1016/j.humimm.2006.12.003 . pasteur-00202632

\section{HAL Id: pasteur-00202632}

https://hal-pasteur.archives-ouvertes.fr/pasteur-00202632

Submitted on 8 Mar 2008

HAL is a multi-disciplinary open access archive for the deposit and dissemination of scientific research documents, whether they are published or not. The documents may come from teaching and research institutions in France or abroad, or from public or private research centers.
L'archive ouverte pluridisciplinaire HAL, est destinée au dépôt et à la diffusion de documents scientifiques de niveau recherche, publiés ou non, émanant des établissements d'enseignement et de recherche français ou étrangers, des laboratoires publics ou privés. 
Modulation of HLA-G and HLA-E expression in human neuronal cells after rabies virus or herpes virus simplex type -1 infections

Françoise Megret ${ }^{1}$, Christophe Prehaud $^{1}$, Mireille Lafage ${ }^{1}$, Philippe Moreau $^{2}$, Nathalie RouasFreiss $^{2}$, Edgardo D Carosella ${ }^{2}$ and Monique Lafon ${ }^{1 *}$

${ }^{1}$ Laboratoire de Neuroimmunologie Virale, Institut Pasteur, Paris, France

${ }^{2}$ Service de Recherche en Hémato-Immunologie, CEA-DSV-DRM, Hôpital Saint Louis, IUH Paris France

Running title: Neuronal HLA-E and G expression upon virus infection

* Corresponding author: Monique Lafon, Laboratoire de Neuroimmunologie Virale, Institut Pasteur, 25, rue du Dr Roux, 75724 Paris Cedex 15, France, tel: 331456887 52, fax: 331406133 12. e-mail: $\underline{\text { mlafon@pasteur.fr }}$

Key words : HLA-G, HLA-E, rabies virus, HSV-1, neurons, Ntera-2-D/1

Abbreviations : RABV (rabies virus), HSV-1 (herpes simplex virus type 1), mAb monoclonal antibody, HCMV ( Human cytomegalovirus) 


\begin{abstract}
HLA-G and E are non classical human MHC class I molecules. They may promote tolerance leading to virus and tumour immune escape. We recently described that the herpes simplex virus type 1 (HSV-1), a neurotropic virus inducing chronic infection and neuron latency, and rabies virus (RABV), a neuronotropic virus triggering acute neuron infection - up-regulate HLA-G expression in human neurons (NT2-N). Surface expression was only detected after RABV infection. We investigated here whether RABV and HSV-1 up regulate HLA-E expression in human neuronal precursors (Ntera-2D/1). We found that RABV and -not HSV1- up regulates HLA-E expression, nevertheless HLA-E could not be detected on the surface of RABV infected Ntera-2D/1. Altogether these data suggest that HLA-G and not HLA-E could contribute to the immune escape of RABV. In contrast, there was no evidence that these molecules are used by latent HSV-1infection. Thus, neurotropic viruses that escape the host immune response totally (RABV) or partially (HSV-1) regulate HLA-G expression on human neuronal cells differentially.
\end{abstract}




\section{INTRODUCTION}

Viruses have developed strategies to facilitate their own dissemination by escaping attack by $\mathrm{T}$ and NK cells [1]. Some viruses induce the apoptosis of $\mathrm{T}$ or NK cells by increasing the production of immunosubversive molecules in the tissues they infect, resulting in the inactivation of $\mathrm{T}$ cells expressing receptors for these molecules. One such molecule, the Ligand of Fas, FasL, has been shown to be involved in the killing of migratory T cells into the nervous system (NS) in rabies virus (RABV) infection [2, 3]. HLA-G, a non classical MHC molecule which expression in cells is up regulated following infection with human cytomegalovirus (HCMV), human immunodeficiency virus (HIV-1) and RABV could also contribute by a similar mechanism to the immunoevasion of these viruses [4-8]. In addition, HIV-1 and HCMV up regulate the expression of another non classical MHC class I molecule, HLA-E at the surface of the infected cells leading to the protection of the infected cells from NK lysis [9] [10] [11-13].

Thus, the capacity of HLA-G to kill $\mathrm{T}$ and NK cells through the binding to the inhibitory receptor KIR2DL4 expressed by NK cells [14-16] or through the binding to CD8 molecules present on T cells [17]- and the capacity of HLA-E to modulate NK function, via its binding to NKCD94/NKG2A receptors [18-20] have been hijacked by viruses to sneak through the innate and adaptative host immune responses.

HLA-G and HLA-E are two non classical Class I (Ib) molecules with a low level of polymorphism. Seven HLA-G isoforms - four membrane-bound (HLA-G1, G2, G3 and G4) and three soluble (HLA-G5, G6 and G7) isoforms-, obtained by means of alternative splicing of a single primary transcript [21] have been identified. The most studied are the membranebound HLA-G1 and soluble HLA-G5 isoforms. Both are associated with $\beta 2$ microglobulin [22]. HLA-G, which was originally thought to be present exclusively in the human placenta $[23,24]$ has also been detected in brain and neural cells $[25,26]$ including human neurons[8]. 
HLA-E is ubiquitously transcribed in most human tissues. It is associated with the $\beta 2$ microglobulin. Surface expression of HLA-E is usually weak suggesting that post translational mechanisms regulate its expression.

The question whether the HLA-E can be employed by neurons during infection of the NS by viruses which are known to escape the adverse host immune response such as RABV $[2,3,8$, 27] or not such as latent strain of HSV-1 (KOS virus) was challenged here. We therefore investigated whether RABV and HSV-1 infected human neurons express HLA-E and whether HLA- E molecules reach the cell surface of the infected neurons.

\section{MATERIALS AND METHODS}

\section{Antibodies and reagents}

Mouse mAb MEM-G/09 specific for the native $\beta 2$-microglobulin-associated HLA-G forms (corresponding to the native HLA-G1 and HLA-G5 isoforms) [28, 29], MEM-E/07 specific for the native HLA-E and MEM-E/02 [28] specific for the HLA-E denaturized heavy chain $(43 \mathrm{kDa})$ molecules were from Exbio. Isotype-matched irrelevant mAbs were obtained from Serotec. Biotinylated W6-32 was from Leinco-Biotechnologies. Phycoerythrin (PE)conjugated streptavidin were purchased from Dako. FITC-conjugated rabbit anti-RABV nucleocapsid $\mathrm{Ab}$ was obtained from Biorad. Pan-ERK antibody was from BD Transduction Signal. Fluoromount-G was obtained from Southern Biotechnology Associates. Alexa Fluor 594-conjugated goat anti-mouse Ab was purchased from Molecular Probes. Biotinylated antimouse IgG was obtained from Amersham. Cell-fix and Fc-Block (rat anti-Fc $\gamma$ III/II receptor $\mathrm{mAb}$ ) were purchased from BD Biosciences. Phosphate Safe extraction Buffer was from Novagen. Protease inhibitor cocktail and Pefabloc SC were obtained from Roche. Hot Start Taq polymerase and RNeasy Protect kits were purchased from Qiagen. Superscript II RT was

obtained from Invitrogen. Agilent RNA Nano LabChips were purchased from Agilent 
Technologies. Protran BA83 Cellulose nitrate $0.2 \mu \mathrm{m}$ membranes were from ShleicherSchuell.

\section{Human cells and viruses.}

Ntera-2D/1 cells (ATCC CRL, 1973) are human neuronal precursors from which human neurons-NT2-N- or mixed cultures of neurons and astrocytes- NT2-N/A- can be differentiated using two different types of differentiation protocols as previously described [8]. M8-pcDNA a HLA-A, B, C, E positive but HLA-G negative melanoma cell line [30] transfected with an hygromycin resistant vector was used as a HLA-E positive control cells.

The laboratory strain CVS (ATCC vr959), a highly pathogenic RABV strain [31] was propagated as previously described [32]. The latent HSV-1 strain KOS [33] was propagated on U373MG. Cells were infected at a multiplicity of infection (MOI) of three if required.

\section{Analysis of gene expression after RABV or HSV-1 infection}

NT2-N/A cells were non-infected or infected with RABV. RNAs were isolated 24h later from both infected and non-infected cultures by using the RNeasy Kit. Duplicate samples obtained two weeks apart were used to exclude experimental variations. Control quality was monitored on Agilent RNA Nano Labchips. Gene expression profiles were analyzed using Affymetrix microarrays (U133 plus2.0) containing probe sets representative of the whole human genome. Experiments were done at the Génopole Strasbourg-Alsace-Lorraine (http://www-genopole.u-strasbg.fr/) by Affymetrix standard protocols (http://www.affymetrix.com/support). Detected probe sets were selected according to the "presence calls" and the fold changes were established by Affymetrix software (Microarray Suite v5.0 and Data Mining Tool v2.0). Only significantly changed probe sets $(\mathrm{p}<0.05)$ were 
considered. Up-regulated genes were distributed into clusters of cell functions using Net Affyx and Gene Ontology Mining tool Softwares.

\section{Standard RT-PCR}

Total RNA was extracted with RNeasy kits 18 h (HSV-1) or 24 h (RABV) after infection. RNA quality was monitored using Agilent RNA Nano Labchips. The first-strand cDNA was synthesized with oligodT primers. $18 S$ rRNA was used as a reference (housekeeping gene). Infection efficiency was assessed by PCR, amplifying $H S V-1$ UL54 or RABV N. RT-PCR was carried out as described in the 13th HLA Workshop report [34] using oligo (dT) primers, and for HLA-E: the primers couples E.251F : 5'-ACACGGAGCGCCAGGGACAC -E.1272R : 5'GTGTGAGGAAGGGGGTCATG (amplicon size $1021 \quad$ bp), $\quad$ E.251F : 5'ACACGGAGCGCCAGGGACAC - HLA-E R 5'-ATCATTTGACTTTTGCTCGGA (amplicon size $258 \mathrm{bp}$ ). The $\phi X 174$ DNA HaeIII digested was used as molecular weight markers.

\section{Detection of total HLA-G, HLA-E and viral antigen}

Infected and non-infected Ntera-2D/1 cells were used to seed $12 \mathrm{~mm}$-diameter glass coverslips (5-7x $10^{5}$ cells/coverslip) $16 \mathrm{~h}$ before infection. After $48 \mathrm{~h}$ (RABV) or $18 \mathrm{~h}$ (HSV-1) of infection, cells were washed once with $\mathrm{Ca}^{2+} \mathrm{Mg}^{2+}$-PBS, fixed by incubation in $4 \%$ PFA for $30 \mathrm{~min}$ at room temperature $(\mathrm{Rt})$, washed again and briefly treated with gelatin solution $(1 \%$ in water) for $5 \mathrm{~min}$ at $4^{\circ} \mathrm{C}$. The cells were then incubated for $30 \mathrm{~min}$ at Rt in $0.3 \%$ TritonX100 in PBS and washed. The surface Ig receptors were blocked by incubation with saturating medium (SM) (2\% BSA and 5\% FCS in PBS) for 30 min at Rt followed by Fcblock $\left(1 \mu \mathrm{g} / 10^{6}\right.$ cells) for $10 \mathrm{~min}$. Total HLA-G or (membrane-bound and intra-cytoplasmic accumulation of HLA-G molecules) was detected by incubation with MEM-G/09 and total 
HLA-E with MEM-G/07 (1 h at Rt) followed by Alexa 594-conjugated goat anti-mouse Ab (1/200). Viral antigen levels was detected in the same series of experiments by incubating fixed cells with FITC-conjugated rabbit Ab directed against RABV (1/30) or against HSV-1 proteins $(1 / 10)$ for $30 \mathrm{~min}$ at Rt. Nuclei were stained with Hoechst 33342. Antibodies and reagents were diluted in SM. Cells were washed with $\mathrm{Ca}^{2+} \mathrm{Mg}^{2+}-\mathrm{PBS}$ and then rinsed in water. Coverslips mounted in Fluoromount-G were analyzed under a Leica DM 5000B UV microscope equipped with a DC 300FX camera. Images were processed with Leica FW 4000 software.

\section{Detection of HLA-A, B, C and HLA-E at the cell surface}

Live (not fixed) cells were used for the detection of HLA molecules at the cell surface. Infected and non-infected cells $\left(5 \times 10^{5}\right.$ cells $)$ were gently detached from the support, washed in $\mathrm{Ca}^{2+} \mathrm{Mg}^{2+}$-PBS and incubated with Fc-Block, followed by MEM-G/02 (HLA-E), biotinylated W6-32 ( $\alpha$-chain of HLA-A, B and C) mAb or the isotype-matched control Ab diluted in staining buffer, (PBS, 1\% FCS, $0.1 \%$ sodium azide) for 30 min each at $4^{\circ} \mathrm{C}$. Cells were washed and incubated for $30 \mathrm{~min}$ at $4^{\circ} \mathrm{C}$ with biotinylated anti-mouse $\mathrm{Ab}$, followed by PEconjugated streptavidin (both in staining buffer). For detection of W6-32, the biotinylated reagent was omitted. Cells were washed again and resuspended in Cell Fix (1/10 in staining buffer) to be analyzed by flow cytometry, using a BD Biosciences FACScalibur equipped with Cell Quest Pro software. HLA expression was detected in $10^{4}$ cells gated to exclude dead cells and cell debris. Levels of HLA expression in this cell population were assessed by determining the frequency of events with FITC signals exceeding a given threshold. Specific fluorescence indices (SFIs) were calculated by dividing the mean fluorescence for infected cells by the mean fluorescence obtained for a similar number of uninfected cells. SFI values greater than 1.25 were considered positive. 


\section{Detection of HLA-E by immunoblotting}

Non-infected or RABV infected Ntera-2D/1 were lyzed in Phosphosafe extraction buffer in presence of protease inhibitor cocktail. Proteins were separated by SDS electrophoresis PAGE. Transferred proteins on Protran BA 83 Cellulose/Nitrate $0.2 \mu \mathrm{m}$ membranes were incubated with MEM-E/02 followed by peroxydase-conjugated anti-mouse Ab. ERK (53kD) was used as an internal standard. Bands were revealed with ECL+ and quantified with FujiFilm Intelligent DarKII LAS 1000.

\section{RESULTS}

RABV up regulates the expression of classical and non classical HLA transcripts in human neuronal cells.

A transcriptome analysis was carried out after RABV infection of neuronal cells by using Affymetrix U133 plus2.0 chips. This study was undertaken in mixed cultures of neurons and astrocytes (NT2-N/A) derivated from the human neuronal precursor Ntera-2D/1 either non infected or infected with RABV (24h). A cut off of a 2-fold increase was used to identify up regulated genes by microarray analysis: RABV-infection up regulated the expression of 2241 genes [35]. Among the up regulated genes, some genes of the MHC class I family were amplified by RABV infection. As shown in Table 1, RABV infection of NT2-N/A increased the expression of classical MHC class I molecules of $H L A-A,-B$ and $-C$ genes by $5.1,7.2,7.2$ fold respectively and the expression of the non classical class I molecules $H L A-E,-F$ and $-G$ genes by 13.4, 6.7 and 6.5 fold respectively. $H L A-H$ (named also HFE) was absent from NT2N/A transcriptome. Among the related MHC class I molecules, MICB gene transcription (x 2.5) but not MICA was also up regulated during RABV infection. 
HLA-E was the gene which transcription was the most increased by RABV infection (x 13.4) In striking contrast, in the same conditions of culture and analysis, transcription of HLA-E was not amplified in NT2-N/A cultures infected by HSV-1 (data not shown)

Thus HLA-E expression in cultures of human neuronal precursors infected by RABV was investigated in more details.

\section{RABV and not HSV-1 up regulated HLA-E transcription in human neuronal cultures}

We used RT-PCR to validate the expression patterns detected by microarrays. Human neurons (NT2-N) were infected for $24 \mathrm{~h}$ with RABV and $18 \mathrm{~h}$ with HSV-1. RNAs were extracted. Virus infections were monitored by RT-PCR, using pairs of primers specific for the $N$ gene of RABV, for the UL54 gene of HSV-1 (data not shown). HLA-E gene transcription was studied by RT-PCR using two sets of primers (Figure 1A and 1B). M8pcDNA cells were used as control of $H L A-E$ expression and $18 S$ as a housekeeping gene (Figure 1C). The data clearly indicated that $H L A-E$ transcription was up regulated after RABV and not after HSV infections. The fact that increased transcription of HLA-E gene was observed also by RT-PCR confirmed the results of transcriptome analysis.

\section{RABV upregulated the HLA-E and HLA-G protein expression in RABV infected human neuronal cells}

Cultures of Ntera-2D1 were either non-infected or infected with RABV for $24 \mathrm{~h}$. Immunoblotting using the MEM-E/02 mAb allowed the detection of HLA-E protein (42kDa) in RABV infected Ntera-2D/1 extracts and not in non-infected ones (Figure 2A). Immunocytochemistry analysis using the MEM-E/07 mAb also allowed HLA-E detection in M8pcDNa cells (Figure 2B) as well as in RABV infected Ntera-2D/1 (Figure 2C a-d), whereas HLA-E was not expressed by non infected cells (Figure 2C e-h) nor in HSV-1 
infected cells (data not shown). Using the HLA-G specific MEM-G/09 mAb, RABV infection was found to up regulate HLA-G expression in human neuronal precursors (Figure 3) as found in human NT2-N cells [8].

\section{HLA-E molecules did not reach the surface of RABV infected}

Cytofluorimetry analysis was performed on permeabilized RABV-infected cells to detect HLA intracellular expression (Left panels of Figure 4) and on non permeabilized RABVinfected cells (Right panels of Figure 4) to detect surface expression. Both internal and surface expression of HLA-A, -B or -C (detected with the W6-32 mAb) increased with RABV infection. In contrast, despite a strong up regulation of intracellular expression of HLA-E surface expression of HLA-E was unchanged in RABV infected and non infected cells. In contrast, in the same staining conditions, HLA-E could be detected on the surface of M8pcDNA (bottom panel of Figure 4). This indicates that despite over expression of HLA-E in the cytoplasm, HLA-E molecules did not reach the surface of the RABV-infected cells (Figure 4).

\section{Discussion}

This study showed that RABV infection triggers the transcription of several class I MHC products including classical (HLA-A, -B and -C) and non classical (HLA-E and -G ) molecules in human neuronal cultures. Activation of gene transcription upon RABV infection led to the production of corresponding proteins. These molecules can reach the cell surface in the case of classical MHC molecules and HLA-G (this study and[8]) and not of HLA-E which remained localized into the cytoplasm of the infected cells.

$H L A-E$ gene is ubiquitously transcribed in most tissues. This should not be the case of human neurons since in absence of infection, $H L A-E$ transcription was almost undetectable in human 
neuronal cells. Up-regulation of $H L A-E$ transcription in neurons was a specific pattern of RABV infection since HSV-1 has no effect on $H L A-E$ expression. Factors which control $H L A-E$ transcription in RABV infected neurons are unknown. IFN- $\gamma$ which has been shown in other cell types to control $H L A-E$ transcription through an upstream STAT-1 binding site $[36,37]$ is probably not involved in HLA-E control by RABV since this virus does not trigger IFN- $\gamma$ transcription in human neurons $[8,38]$. We have previously shown that HSV-1 and RABV infections modulate the expression of the $H L A-G$ gene in different ways: HSV-1 up regulated mainly the isoforms $H L A-G 5$ and $G 3$, whereas RABV up regulated mainly $H L A$ G1[8]. This emphasizes that human neurons use sophisticated patterns of $H L A-G$ and $E$ regulation and that $\mathrm{HSV}-1$ and $\mathrm{RABV}$ could be appropriate tools for their analysis.

In contrast to classical MHC class I which surface expression was increased by RABV infection, HLA-E molecules could not be detected on the cell surface, suggesting they cannot be exported. Such a pattern has been observed in human tumours which may not express HLA-E on cell surface despite the expression of HLA class I, presence of intracellular HLAE, HLA-E transcript and expression of $\beta 2$ microglobulin [39]. Surface expression of HLA-E, which is usually weak, can be limited by at least two factors. Surface expression of HLA-E required association with leader peptides derived from HLA-C, HLA-G and -A molecules in a TAP dependent manner (42-45). HLA-E surface expression is also dependent on availability of $\beta 2$ microglobulin. HLA-E is known to have a weaker affinity for $\beta 2$ microglobulin resulting in competition for $\beta 2$ microglobulin in favor of other HLA class I a [39]. The export of HLA-A, -B and -C at the surface of the infected neurons and not of HLA-E could reflect the competition between HLA-E and other MHC Class I for $\beta 2$ microglobulins. In the case of cells infected by viruses, such as HIV, CMV and hepatitis C virus, HLA-E surface export is favored by its association with virally encoded peptides showing homology with HLA class I leader peptides. These peptides are used in place of the MHC class I leader peptides, whose 
expression are down regulated by these viruses. In absence of surface expression of MHC class I, HLA-E export to the surface and functional recognition of HLA-E by the CD94/NKG2A molecules expressed by NK cells protect the infected cells form NK lysis [11, 13, 40]. In HCMV infected cells, HLA-E only acquires a CD94/NKG2A receptor conformation if a ligand derived from the UL40 signal sequences of HCMV is bound. VMAPRTLIL is the UL40 HCMV sequence which stabilizes HLA-E expression [13]. Such sequence and derivated ones are not encoded by any RABV proteins (data not shown). This is consistent with the absence of HLA-E surface expression in RABV infected neurons. Thus it is unlikely that up regulation of HLA-E constitutes a protective mechanism against NK lysis. This mechanism functions in cells infected by viruses which down regulate classical MHC class I from the cell surface. Expression of classical MHC class I molecules is not down regulated by $\mathrm{RABV}$ expression, indicating that $\mathrm{RABV}$ infected neurons have little chance to be targeted by NK cells which presence in human rabies have been detected but whose protective function against the virus progression is dubious [41, 42].

Functional studies have identified FasL and HLA-G as important mediators of immune tolerance $[23,24,43,44][45-47]$. RABV was found to up regulate FasL and membranebound HLA-G1 molecules, thereby potentially impeding host antiviral responses based on $\mathrm{T}$ cells. We suggest that HLA-G1 and FasL expression on the surface of neural cells -neurons and others including astrocytes) during RABV infection protects infected cells against $\mathrm{T}$ surveillance, contributing to the establishment of a local subversive environment adverse to the host immune reaction (Figure 5). In contrast, latent HSV-1 does not seem to use such up regulation of HLA-G on the cell surface nor to export HLA-E to the cell surface despite a down regulation of the classical MHC class I molecules. Defects in surface HLA-G expression or expression at too low a density, as well as absence of HLA-E shield against NK surveillance may maintain immune pressure, leading to latency. 
It is intriguing to note that RABV infected neurons and tumors are two conditions in which HLA-E is actively transcribed and where HLA-E proteins accumulate in the cytoplasm. Given the remarkable degree of conservation of HLA-E, HLA-E control during viral infections and tumorgenesis may indicate a possible wider biologic role of HLA-E [48] which remains to be defined.

\section{Acknowledgments}

This work was supported by internal grants of the Pasteur Institute and CEA. 
Table 1

\begin{tabular}{|c|c|c|c|}
\hline Gene Symbol & Name & Affymetrix & $\begin{array}{c}\text { Fold } \\
\text { RABV } \\
\text { NT2-N/A }\end{array}$ \\
\hline HLA-A & $\begin{array}{c}\text { Major } \\
\text { histocompatibility } \\
\text { complex, class I, A }\end{array}$ & 215313 & 5.1 \\
\hline HLA-B & $\begin{array}{c}\text { Major } \\
\text { histocompatibility } \\
\text { complex, class I, B }\end{array}$ & 208729 & 7.2 \\
\hline HLA-C & $\begin{array}{c}\text { Major } \\
\text { histocompatibility } \\
\text { complex, class I, C } \\
\text { (alpha chain) }\end{array}$ & 211799 & 7.2 \\
\hline HLA-E & $\begin{array}{c}\text { Major } \\
\text { histocompatibility } \\
\text { complex, class I, E }\end{array}$ & 200904 & 13.4 \\
\hline HLA-F & $\begin{array}{c}\text { Major } \\
\text { histocompatibility } \\
\text { complex, class I, F }\end{array}$ & 204806 & 6.7 \\
\hline HLA-G & $\begin{array}{c}\text { Major } \\
\text { histocompatibility } \\
\text { complex, class I, G }\end{array}$ & 217436 & 6.5 \\
\hline MICB & $\begin{array}{c}\text { MHC class I } \\
\text { polypeptide related } \\
\text { sequence B }\end{array}$ & 206247 & 2.5 \\
\hline
\end{tabular}




\section{Legends}

Figure 1 RABV and not $\mathrm{HSV}-1$ upregulate $H L A-E$ expression in neuronal cells. $H L A-E$ transcript levels were analysed in N.I., HSV-1 or RABV-infected NT2-N cells and in M8pcDNA a HLA-E expressing cell line, by RT-PCR, using two sets of HLA-G primers: A) E 251 F / HLA-E R -amplicon size 258bp- or B) E251 F/ E1272 R -amplicon size 1021bp. C) $18 \mathrm{~S}$, a housekeeping gene, was used for normalization. MW is for molecular weight.

\section{Figure 2 RABV triggers HLA-E expression in human neuronal precursors.}

A) HLA-E protein expression was monitored in NI and 24h RABV infected Ntera-2D/1 extracts by immunoblotting using MEM-E/02 mAb. HLA-E (42kDa) expression could be detected in RABV infected cells and not in NI. ERK $(53 \mathrm{kDa})$ was used as an internal marker. B and C) HLA-E expression was detected by immunocytochemistry using MEM-E/07 mAb (red) in B) the HLA-E expressing M8pcDNA cells and C) RABV infected Ntera-2D/1 (Ntera) cells $(\mathbf{C}$, a-d) but not in the non-infected (NI) cells (e-h). Nuclei appeared in blue with the Hoechst staining (a, d, e and h). Viral antigens are in green (c and d). Control consists in staining with an irrelevant $\mathrm{mAb}$. Bars represent $10 \mu \mathrm{m}$.

\section{Figure 3 RABV triggers HLA-G expression in human neuronal precursors}

HLA-G expression was detected by immunocytochemistry using MEM-G/09 mAb (red) in RABV infected Ntera-2D/1 cells (a-d) but not in the non-infected (NI) Ntera-2D/1 cells (e-h). Nuclei appeared in blue with the Hoechst staining (a, d, e and h). Viral antigens are in green (c-d). Bars represent $10 \mu \mathrm{m}$. 
Figure 4. HLA-E proteins are not exported at the surface of the infected neuronal precursors. Intracellular and surface expression of HLA-E were determined by cytofluorimetry. Permeabilized (left panels) and non permeabilized RABV infected and NI Ntera-2D/1 (right panels) were stained with MEM-E/07 (detection of HLA-E) and with W6$32 \mathrm{mAb}$ (detection of HLA-A, B and C). Intensity of fluorescence was monitored with a cytofluorimeter in NI (solid histogram) and in RABV infected cells (lines).. Capacity of MEM-E/07 Ab to detect HLA-E cell surface was checked on M8pcDNA- a cell line naturally expressing HLA-E and not HLA-G-(bottom panel). Non permeabilized M8pcDNA were stained with MEM-E/07 (line) or with irrelevant Ab MEM-G9 (solid histograms).

Figure 5 Role of HLA-G1/5 and FasL in the immunoevasive strategy of RABV. Upregulation of HLAG1/5 and FasL in the infected neurons $[2,8]$ and in astrocytes [8] in the neighborhood may create a local immunosubversive environment in the infected nervous system which may contribute to destruction of $\mathrm{T}$ cells and participate to the immunoevasive strategies elaborated by RABV. Despite the upregulation of HLA-E expression in the cytoplasm of the infected neurons, HLA-E molecules which do not reach the cell surface do not participate to the immunoevasive strategy of RABV. Similarly, HLA-G which transcription and cytoplasmic expression is increased in human neurons infected by a latent strain of HSV-1 would not confer any protection against T and NK cell lysis since HLA-G molecules do not reach the surface of the latently infected neurons. 


\section{REFERENCES}

1. Alcami A, Koszinowski UH: Viral mechanisms of immune evasion. Trends Microbiol 8(9):410, 2000.

2. Baloul L, Camelo S, Lafon M: Up-regulation of Fas ligand (FasL) in the central nervous system: a mechanism of immune evasion by rabies virus. J Neurovirol 10(6):372, 2004.

3. Lafon M: Subversive neuroinvasive strategy of rabies virus. Arch Virol Suppl (18):149, 2004.

4. Onno M, Pangault C, Le Friec G, Guilloux V, Andre P, Fauchet R: Modulation of HLA-G antigens expression by human cytomegalovirus: specific induction in activated macrophages harboring human cytomegalovirus infection. J Immunol 164(12):6426, 2000.

5. Pangault C, Le Friec G, Caulet-Maugendre S, Lena H, Amiot L, Guilloux V, Onno M, Fauchet R: Lung macrophages and dendritic cells express HLA-G molecules in pulmonary diseases. Hum Immunol 63(2):83, 2002.

6. Lozano JM, Gonzalez R, Kindelan JM, Rouas-Freiss N, Caballos R, Dausset J, Carosella ED, Pena J: Monocytes and T lymphocytes in HIV-1-positive patients express HLA-G molecule. Aids 16(3):347, 2002.

7. Cabello A, Rivero A, Garcia MJ, Lozano JM, Torre-Cisneros J, Gonzalez R, Duenas G, Galiani MD, Camacho A, Santamaria M, Solana R, Montero C, Kindelan JM, Pena $\mathrm{J}$ : HAART induces the expression of HLA-G on peripheral monocytes in HIV-1 infected individuals. Hum Immunol 64(11):1045, 2003.

8. Lafon M, Prehaud C, Megret F, Lafage M, Mouillot G, Roa M, Moreau P, RouasFreiss N, Carosella ED: Modulation of HLA-G expression in human neural cells after neurotropic viral infections. J Virol 79(24):15226, 2005.

9. Cohen GB, Gandhi RT, Davis DM, Mandelboim O, Chen BK, Strominger JL, Baltimore D: The selective downregulation of class I major histocompatibility complex proteins by HIV-1 protects HIV-infected cells from NK cells. Immunity 10(6):661, 1999.

10. Hill A, Jugovic P, York I, Russ G, Bennink J, Yewdell J, Ploegh H, Johnson D: Herpes simplex virus turns off the TAP to evade host immunity. Nature 375(6530):411, 1995.

11. Nattermann J, Nischalke HD, Hofmeister V, Kupfer B, Ahlenstiel G, Feldmann G, Rockstroh J, Weiss EH, Sauerbruch T, Spengler U: HIV-1 infection leads to increased HLA-E expression resulting in impaired function of natural killer cells. Antivir Ther 10(1):95, 2005.

12. Hofmeister V, Weiss EH: HLA-G modulates immune responses by diverse receptor interactions. Semin Cancer Biol 13(5):317, 2003.

13. Tomasec P, Braud VM, Rickards C, Powell MB, McSharry BP, Gadola S, Cerundolo V, Borysiewicz LK, McMichael AJ, Wilkinson GW: Surface expression of HLA-E, an inhibitor of natural killer cells, enhanced by human cytomegalovirus gpUL40. Science 287(5455):1031, 2000.

14. Shiroishi M, Tsumoto K, Amano K, Shirakihara Y, Colonna M, Braud VM, Allan DS, Makadzange A, Rowland-Jones S, Willcox B, Jones EY, van der Merwe PA, Kumagai I, Maenaka K: Human inhibitory receptors Ig-like transcript 2 (ILT2) and ILT4 compete with CD8 for MHC class I binding and bind preferentially to HLA-G. Proc Natl Acad Sci U S A 100(15):8856, 2003.

15. Colonna M, Navarro F, Bellon T, Llano M, Garcia P, Samaridis J, Angman L, Cella M, Lopez-Botet M: A common inhibitory receptor for major histocompatibility 
complex class I molecules on human lymphoid and myelomonocytic cells. J Exp Med 186(11):1809, 1997.

16. Cosman D, Fanger N, Borges L, Kubin M, Chin W, Peterson L, Hsu ML: A novel immunoglobulin superfamily receptor for cellular and viral MHC class I molecules. Immunity 7(2):273, 1997.

17. Fournel S, Aguerre-Girr M, Huc X, Lenfant F, Alam A, Toubert A, Bensussan A, Le Bouteiller P: Cutting edge: soluble HLA-G1 triggers CD95/CD95 ligand-mediated apoptosis in activated CD8+ cells by interacting with CD8. J Immunol 164(12):6100, 2000.

18. Lee N, Llano M, Carretero M, Ishitani A, Navarro F, Lopez-Botet M, Geraghty DE: HLA-E is a major ligand for the natural killer inhibitory receptor CD94/NKG2A. Proc Natl Acad Sci U S A 95(9):5199, 1998.

19. Llano M, Lee N, Navarro F, Garcia P, Albar JP, Geraghty DE, Lopez-Botet M: HLAE-bound peptides influence recognition by inhibitory and triggering CD94/NKG2 receptors: preferential response to an HLA-G-derived nonamer. Eur J Immunol 28(9):2854, 1998.

20. Lee N, Malacko AR, Ishitani A, Chen MC, Bajorath J, Marquardt H, Geraghty DE: The membrane-bound and soluble forms of HLA-G bind identical sets of endogenous peptides but differ with respect to TAP association. Immunity 3(5):591, 1995.

21. Carosella ED, Moreau P, Le Maoult J, Le Discorde M, Dausset J, Rouas-Freiss N: HLA-G molecules: from maternal-fetal tolerance to tissue acceptance. Adv Immunol 81:199, 2003.

22. Moreau P, Rousseau P, Rouas-Freiss N, Le Discorde M, Dausset J, Carosella ED: HLA-G protein processing and transport to the cell surface. Cell Mol Life Sci 59(9):1460, 2002.

23. Carosella ED, Paul P, Moreau P, Rouas-Freiss N: HLA-G and HLA-E: fundamental and pathophysiological aspects. Immunol Today 21(11):532, 2000.

24. Carosella ED, Moreau P, Aractingi S, Rouas-Freiss N: HLA-G: a shield against inflammatory aggression. Trends Immunol 22(10):553, 2001.

25. Maier S, Geraghty DE, Weiss EH: Expression and regulation of HLA-G in human glioma cell lines. Transplant Proc 31(4):1849, 1999.

26. Wiendl H, Mitsdoerffer M, Hofmeister V, Wischhusen J, Bornemann A, Meyermann R, Weiss EH, Melms A, Weller M: A functional role of HLA-G expression in human gliomas: an alternative strategy of immune escape. J Immunol 168(9):4772, 2002.

27. Lafon M: Modulation of the immune response in the nervous system by rabies virus. Curr Top Microbiol Immunol 289:239, 2005.

28. Menier C, Saez B, Horejsi V, Martinozzi S, Krawice-Radanne I, Bruel S, Le Danff C, Reboul M, Hilgert I, Rabreau M, Larrad ML, Pla M, Carosella ED, Rouas-Freiss N: Characterization of monoclonal antibodies recognizing HLA-G or HLA-E: new tools to analyze the expression of nonclassical HLA class I molecules. Hum Immunol 64(3):315, 2003.

29. Fournel S, Huc X, Aguerre-Girr M, Solier C, Legros M, Praud-Brethenou C, Moussa M, Chaouat G, Berrebi A, Bensussan A, Lenfant F, Le Bouteiller P: Comparative reactivity of different HLA-G monoclonal antibodies to soluble HLA-G molecules. Tissue Antigens 55(6):510, 2000.

30. Paul P, Rouas-Freiss N, Khalil-Daher I, Moreau P, Riteau B, Le Gal FA, Avril MF, Dausset J, Guillet JG, Carosella ED: HLA-G expression in melanoma: a way for tumor cells to escape from immunosurveillance. Proc Natl Acad Sci U S A 95(8):4510, 1998. 
31. Camelo S, Lafage M, Lafon M: Absence of the p55 Kd TNF-alpha receptor promotes survival in rabies virus acute encephalitis. J Neurovirol 6(6):507, 2000.

32. Thoulouze MI, Lafage M, Montano-Hirose JA, Lafon M: Rabies virus infects mouse and human lymphocytes and induces apoptosis. J Virol 71(10):7372, 1997.

33. Smith KO: Relationship between the Envelope and the Infectivity of Herpes Simplex Virus. Proc Soc Exp Biol Med 115:814, 1964.

34. Paul P, Rouas-Freiss N, Moreau P, Cabestre FA, Menier C, Khalil-Daher I, Pangault C, Onno M, Fauchet R, Martinez-Laso J, Morales P, Villena AA, Giacomini P, Natali PG, Frumento G, Ferrara GB, McMaster M, Fisher S, Schust D, Ferrone S, Dausset J, Geraghty D, Carosella ED: HLA-G, -E, -F preworkshop: tools and protocols for analysis of non-classical class I genes transcription and protein expression. Hum Immunol 61(11):1177, 2000.

35. Prehaud C M, F, Lafage, M and, Lafon M: Human astrocytes provide an inflammatory environment to human neurons following rabies virus infection. submitted, 2007.

36. Gustafson KS, Ginder GD: Interferon-gamma induction of the human leukocyte antigen-E gene is mediated through binding of a complex containing STAT1alpha to a distinct interferon-gamma-responsive element. J Biol Chem 271(33):20035, 1996.

37. Gobin SJ, van den Elsen PJ: Transcriptional regulation of the MHC class Ib genes HLA-E, HLA-F, and HLA-G. Hum Immunol 61(11):1102, 2000.

38. Prehaud C, Megret F, Lafage M, Lafon M: Virus infection switches TLR-3-positive human neurons to become strong producers of beta interferon. J Virol 79(20):12893, 2005.

39. Marin R, Ruiz-Cabello F, Pedrinaci S, Mendez R, Jimenez P, Geraghty DE, Garrido F: Analysis of HLA-E expression in human tumors. Immunogenetics 54(11):767, 2003.

40. Nattermann J, Nischalke HD, Hofmeister V, Ahlenstiel G, Zimmermann H, Leifeld L, Weiss EH, Sauerbruch T, Spengler U: The HLA-A2 restricted T cell epitope HCV core 35-44 stabilizes HLA-E expression and inhibits cytolysis mediated by natural killer cells. Am J Pathol 166(2):443, 2005.

41. Sriwanthana B, Hemachudha T, Griffin DE, Manutsathit S, Tweardy D, Phanuphak P: Lymphocyte subsets in human encephalitic and paralytic rabies. Acta Neurol Scand 80(4):287, 1989.

42. Panpanich T, Hemachudha T, Piyasirisilp S, Manatsathit S, Wilde H, Phanuphak P: Cells with natural killer activity in human rabies. Clin Exp Immunol 89(3):414, 1992.

43. Wiendl H, Mitsdoerffer M, Weller M: Hide-and-seek in the brain: a role for HLA-G mediating immune privilege for glioma cells. Semin Cancer Biol 13(5):343, 2003.

44. Le Discorde M, Moreau P, Sabatier P, Legeais JM, Carosella ED: Expression of HLA$\mathrm{G}$ in human cornea, an immune-privileged tissue. Hum Immunol 64(11):1039, 2003.

45. Choi C, Benveniste EN: Fas ligand/Fas system in the brain: regulator of immune and apoptotic responses. Brain Res Brain Res Rev 44(1):65, 2004.

46. Medana I, Li Z, Flugel A, Tschopp J, Wekerle H, Neumann H: Fas ligand (CD95L) protects neurons against perforin-mediated $\mathrm{T}$ lymphocyte cytotoxicity. J Immunol 167(2):674, 2001.

47. Griffith TS, Brunner T, Fletcher SM, Green DR, Ferguson TA: Fas ligand-induced apoptosis as a mechanism of immune privilege. Science 270(5239):1189, 1995.

48. Knapp LA, Cadavid LF, Watkins DI: The MHC-E locus is the most well conserved of all known primate class I histocompatibility genes. J Immunol 160(1):189, 1998. 


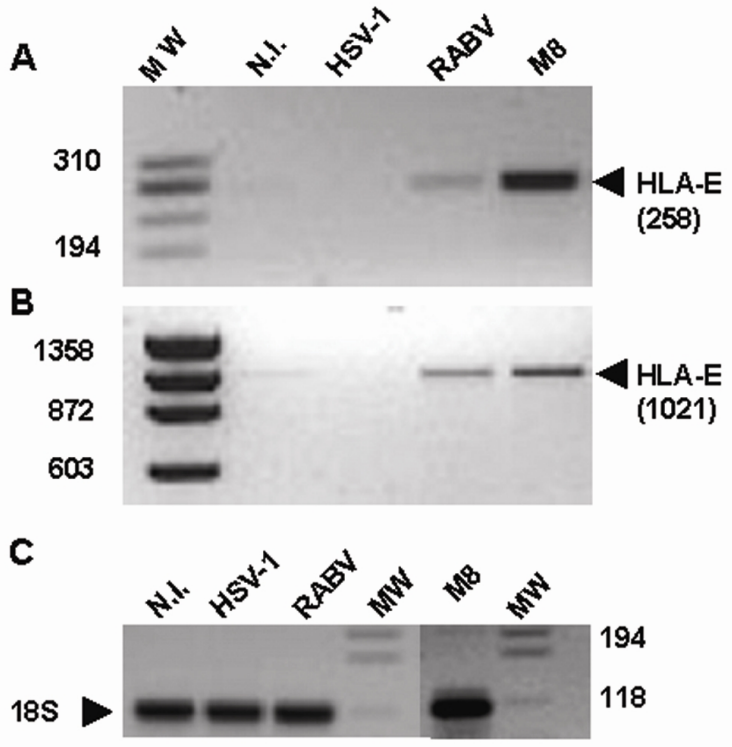


HLA-E Control
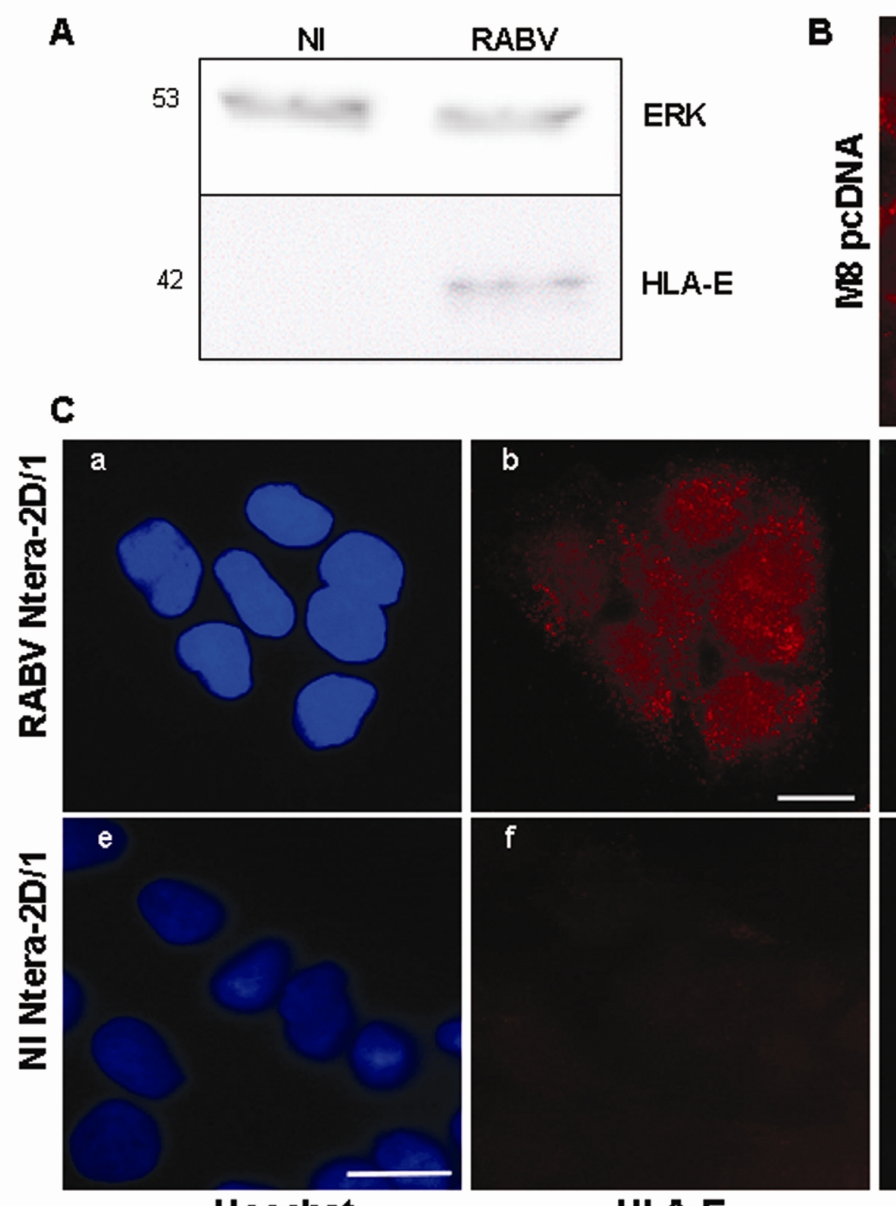
Hoechst

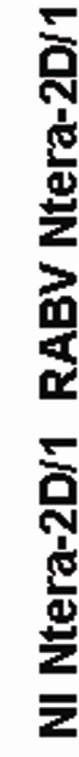

HLA-G

RABV Ag

Merge

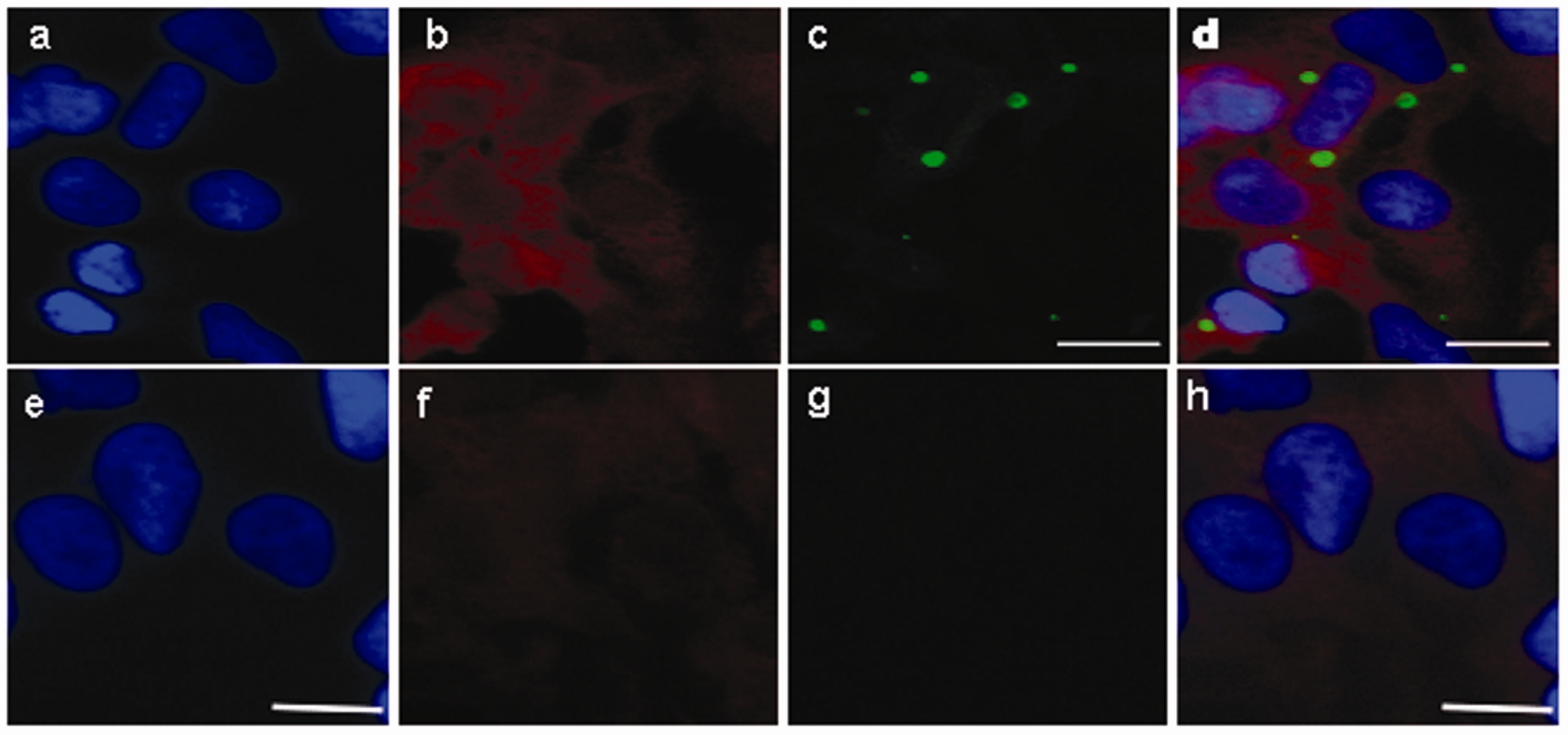


Intra cellular expression
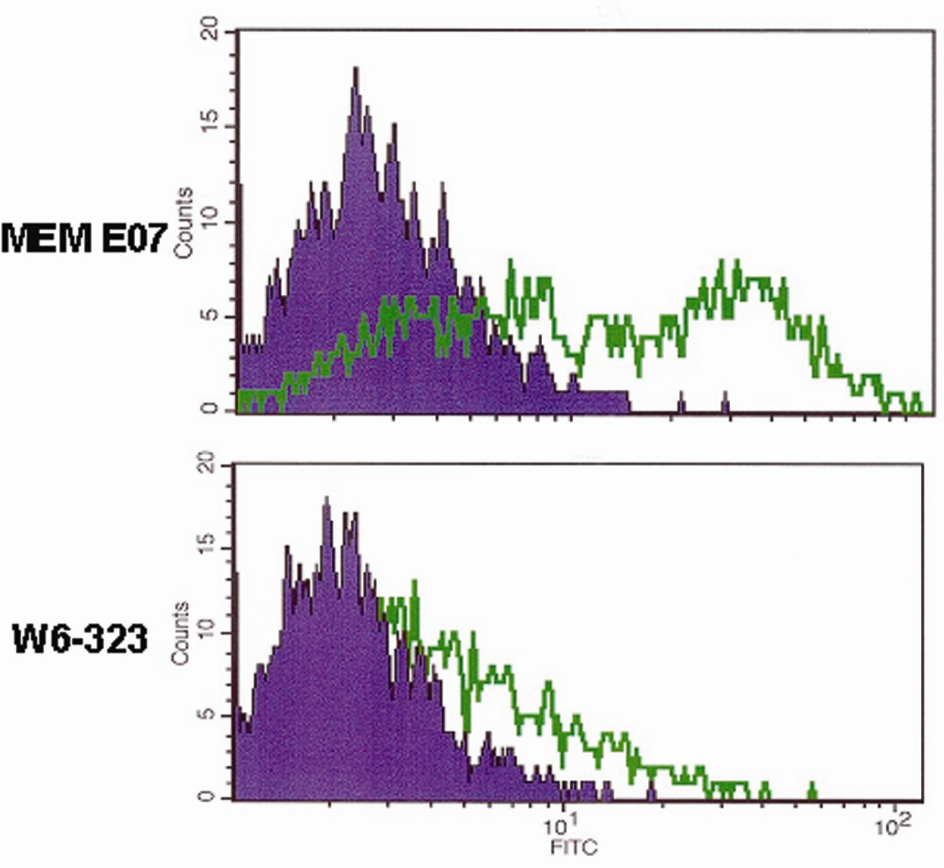

Surface expression
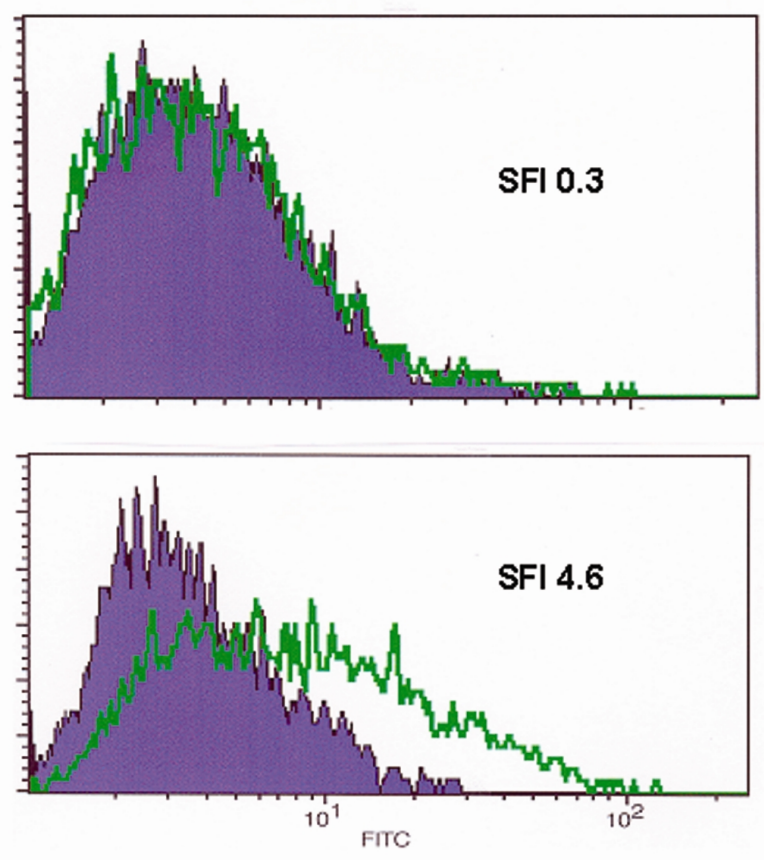

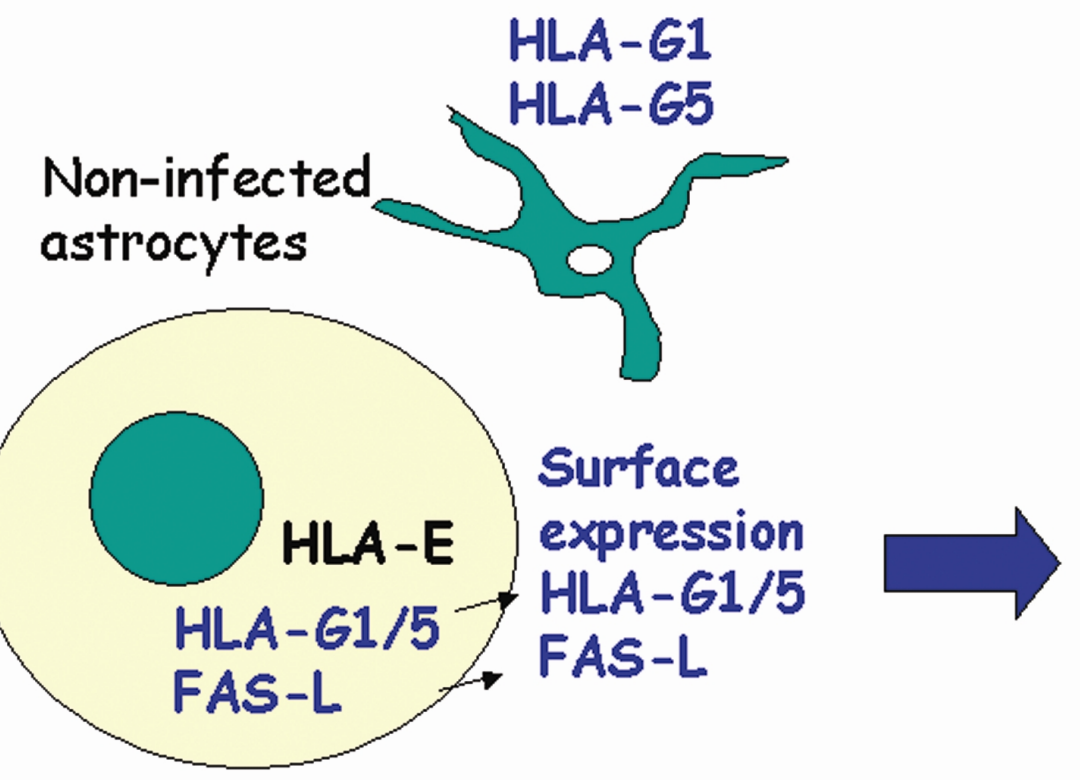

\section{Immunosubversion}

Neurons infected by rabies virus 